\title{
Studies on Gluconeogenesis, Protein Synthesis and Cyclic AMP Levels in Isolated Hepatocytes from Alloxan Diabetic Rats*
}

\author{
S. R. Wagle, W. R. Ingebretsen, Jr. and L. Sampson \\ Dept. of Pharmacology, Indiana University School of Medicine, Indianapolis, Indiana USA
}

Received: March 3, 1975, and in revised form: June 3, 1975

\begin{abstract}
Summary. Alloxan diabetic rats maintained on protamine zinc insulin for two weeks were used for these studies. Hepatocytes were isolated from these rats at various time intervals after withdrawal of insulin $(0,48,72$ and $96 \mathrm{hr})$. Gluconeogenesis with various concentrations of lactate and fructose was studied. Both lactate and fructose stimulated gluconeogenesis and showed progressive increases in glucose production up to $72 \mathrm{hr}$ after the insulin withdrawal. Glucose production decreased at $96 \mathrm{hr}$. Protein synthesis in isolated hepatocytes from diabetic liver cells, as measured by the incorporation of radioactive isoleucine, valine and phenylalanine
\end{abstract}

into protein, showed a decrease (5- to 6-fold) with time after insulin withdrawal. Glucagon $\left(10^{-6} \mathrm{M}\right)$ alone increased cyclic AMP levels 10 -fold in liver cells, in isolated cells from rats maintained on insulin $(0 \mathrm{hr})$ or from rats withdrawn from insulin for $48 \mathrm{hr}$. The ability of glucagon to elevate cyclic AMP levels in isolated diabetic liver cells decreases $72 \mathrm{hr}$ following insulin withdrawal.

Kev words: Gluconeogenesis, protein synthesis, cyclic AMP, alloxan diabetes.
In order to define more accurately the actions of insulin on cellular metabolism, attempts have been made to describe the sequential biochemical changes resulting from insulin administration and withdrawal in alloxan diabetic rats [1-3]. When insulin is administered to diabetic animals the changes produced not only result from correction of insulin deficiency but also represent corrections of secondary effects caused by long standing insulin deficiency. It is well known that insulin deficiency causes increases in glucose production (4-8) and decreases in protein synthesis $[9,10]$. These studies have been previously carried out using intact animals, liver slices and perfused liver. In the present studies we report sequential changes in gluconeogenesis, protein synthesis and cyclic AMP levels in isolated hepatocytes isolated from alloxan diabetic rats withdrawn from insulin.

\section{Materials and Methods}

\section{Animals}

Male, Cox rats weighing between 180-220 g were used. They were fed ad libitum on Purina Laboratory Chow. Alloxan diabetes was produced by intravenous

* Supported by U.S.P.H.S. Grant Number GM 953, AM 14340 and NDEA Title V. injections of alloxan monohydrate $(40 \mathrm{mg} / \mathrm{kg}$ of body weight) in the manner described previously [4]. Rats exhibiting blood glucose levels greater than $300 \mathrm{mg}$ percent five days following alloxan administration were started on insulin and maintained on 4 units protamine zinc insulin (Lilly) daily for two weeks prior to use. These diabetic rats were used at various time intervals after the withdrawal of protamine zinc insulin $(0,48,72,96 \mathrm{hr})$. Both diabetic and normal rats weighing between $180-220 \mathrm{~g}$ were used for all the studies reported here.

\section{Isolation of Hepatocytes}

Normal and diabetic rats were anaesthetized with Na-pentobarbital and the liver was removed rapidly and placed in a Miller perfusion apparatus, perfused for $15 \mathrm{~min}$ with $100 \mathrm{ml}$ of Hanks calcium free buffer containing $1.5 \%$ albumin (Sigma Fraction V) and 10 $\mathrm{mg}$ each of streptomycin and penicillin G. Following this initial perfusion, collagenase ( $20 \mathrm{mg}$, Sigma Type I, 130 units $/ \mathrm{mg}$ ) was added and perfusion was continued for $10-15 \mathrm{~min}$. The liver was removed, finely minced and bubbled gently with $95 \% \mathrm{O}_{2}$ and $5 \% \mathrm{CO}_{2}$ for $1 \mathrm{~min}$. Cells were isolated as described previously $[11,12]$ and were brought to a final volume of $30-40$ $\mathrm{ml}$. Isolated hepatocytes were used immediately for all metabolic studies. 


\section{Incubation of Hepatocytes}

A one $\mathrm{ml}$ aliquot of the final cell suspension (65-75 $\mathrm{mg}$ ) was incubated in $3 \mathrm{ml}$ of Umbreit Ringer bicarbonate buffer $(25 \mathrm{mM})$ in stoppered one ounce plastic vials (Nalgene 2002) with various gluconeogenic substrates. The vials were gassed with $95 \% \mathrm{O}_{2}$ and $5 \% \mathrm{CO}_{2}$ for $5 \mathrm{~min}$ and cells were incubated for one hr. At the end of incubation the vial contents were placed in ice cold conical centrifuge tubes and were centrifuged at $2000 \mathrm{rpm}$ in an International centrifuge for $10 \mathrm{~min}$. The supernatant was assayed for glucose. For the studies on amino acid incorporation into protein, cells were incubated as described above and at the end of the incubation the vial contents were deproteinized by the addition of trichloroacetic acid and radioactivity into protein was assayed as described previously [13]. Cyclic AMP determination was carried out after the cells were incubated for $2 \mathrm{~min}$ in a Krebs Ringer phosphate buffer ( $\mathrm{pH} \mathrm{7.4).} \mathrm{Cyclic}$ AMP was assayed by a competitive protein kinase binding assay of Gilman [14] in entire vial contents after deproteinizing with trichloroacetic acid [15]. Glucose was estimated by the glucose oxidase method [16]. Cell counts were determined using a haemocytometer.

\section{Preparation of Electron Micrographs}

The ultrastructural studies were carried out by thin section electron microscopy on a Sieman IA polarizing electron microscope. Cells, immediately after isolation, were fixed overnight at $0^{\circ} \mathrm{C}$ with $2 \%$ glutaraldehyde in $0.1 \mathrm{M}$ Na phosphate ( $\mathrm{pH} 7.3$ ) buffer. The cells were rinsed twice with $0.1 \mathrm{M} \mathrm{Na}$ phosphate buffer and post-fixed with $2 \%$ osmium tetroxide in $0.05 \mathrm{M} \mathrm{Na}$ phosphate buffer for one hr at $0^{\circ} \mathrm{C}$. They were rinsed again in $0.05 \mathrm{M}$ Na phosphate buffer and dehydrated in a graded ethanol series to $100 \%$ ethanol. Infiltration was completed with propylene oxide and samples were embedded in Epon-812 resin. Thin sections were cut with a LKB ultratome. They were stained with $2 \%$ uranyl acetate in absolute ethanol and post-stained with Reynolds lead citrate [17].

\section{Results}

\section{Microscopic Studies}

The hepatocytes shown in Fig. 1 are typical of the cells isolated in the present study for normal fed animals. The liver cells are completely dissociated from each other and demonstrate distinct cell membranes and not a single broken cell. Similar cell preparations were obtained from diabetic animals. Electron microscopic studies (Fig. 2) of a normal cell show intact cell membranes, mitochondria and parallel strands of rough endoplasmic reticulum. Fig. 3 is an electron micrograph of an isolated cell from a $72 \mathrm{hr}$ diabetic rat. It can be seen that the diabetic cell shows an increase in lipid, a decrease in glycogen, less parallel strands of polyribosomes, more smooth endoplasmic reticulum, and many large vacuoles as compared to normal cell preparations (Fig. 2).

\section{Studies on Gluconeogenesis}

Studies on glucose production with various concentrations of lactate and fructose are summarized in Table 1 and 2 . Net glucose production by isolated hepatocytes progressively increased with time up to $72 \mathrm{hr}$ after the last in vivo insulin injection. Glucose production decreased at $96 \mathrm{hr}$. Glucose production $48 \mathrm{hr}$ after termination of insulin treatment was similar to that observed in cells from $18-24 \mathrm{hr}$ fasted rats [12]. Maximal glucose production was observed 72 $\mathrm{hr}$ following the withdrawal of insulin with $10 \mathrm{mM}$ gluconeogenic precursors. Increasing the concentrations of lactate or fructose above $10 \mathrm{mM}$ did not increase further glucose production at any time after insulin withdrawal. These results are in agreement with the findings of Wagle and Ashmore [4-8] using liver slices and with those of Jefferson et al. [18] using perfused liver. The hepatic glucose production is increased in diabetes.

\section{Studies on Cyclic AMP Levels}

The effects of insulin withdrawal on cyclic AMP levels are presented in Table 3. Theophylline by itself did not increase cyclic AMP levels. Glucagon $\left(10^{-6} \mathrm{M}\right)$ alone or in the presence of theophylline increased cyclic AMP levels was decreased in diabetic rats deprived of insulin. Basal cyclic AMP levels were inrats withdrawn from insulin for $40 \mathrm{hr}$. This ability of glucagon, or glucagon with theophylline, to elevate cyclic AMP levels was decreased in diabetic rats deprived of insulin. Basal cyclic AMP levels were increased 72 or $96 \mathrm{hr}$ after the withdrawal of insulin as compared to $48 \mathrm{hr}$. Similar increases in basal cyclic AMP levels in perfused liver from acute diabetic rats have been reported by Jefferson et al. [18].

\section{Studies on Incorporation of Amino Acids into Protein}

The effects of insulin withdrawal on protein synthesis are presented in Table 4 . The rate of incorporation of ${ }^{14} \mathrm{C}$ isoleucine, valine and phenylaline 


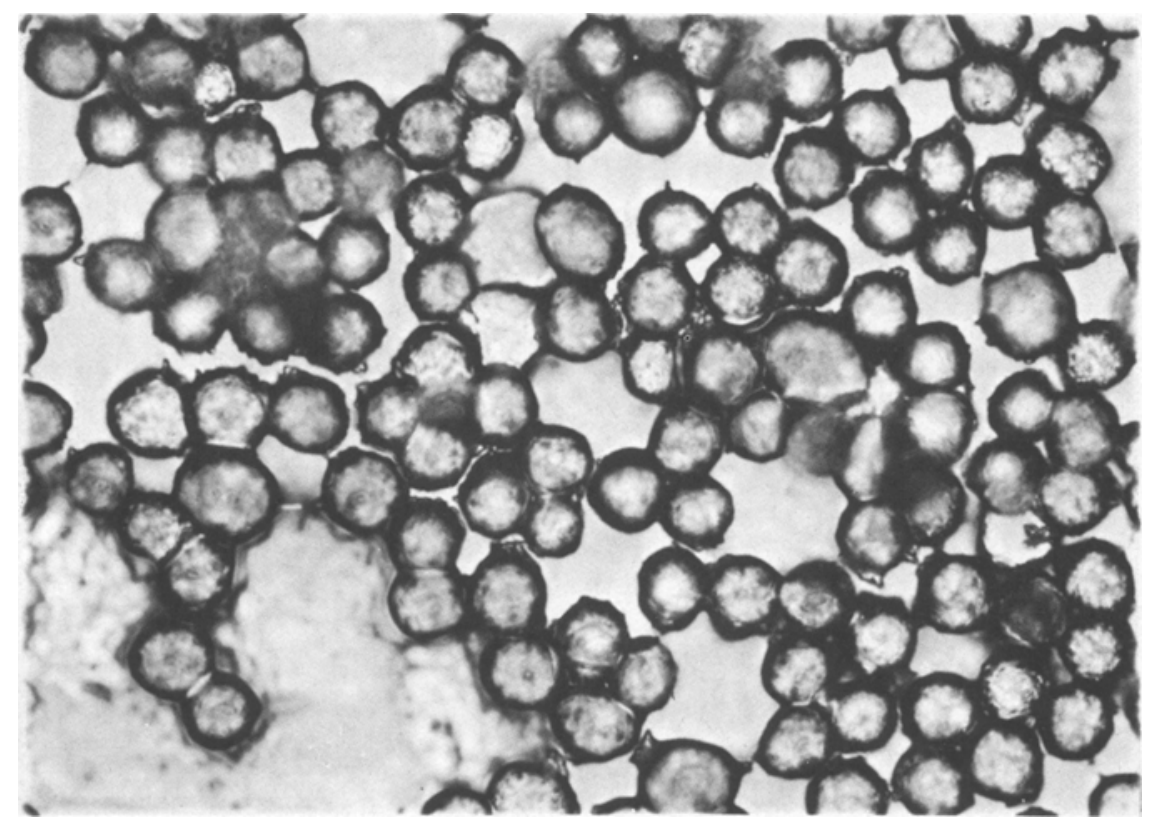

Fig. 1. Light micrograph $(600 \times$ mag $)$ of normal isolated lever cells just prior to incubation. Liver cells demonstrate intact cell membranes as well as nuclear and cytoplasmic compartments. Few, if any red blood cells, Kupffer cells or damaged hepatocytes are present

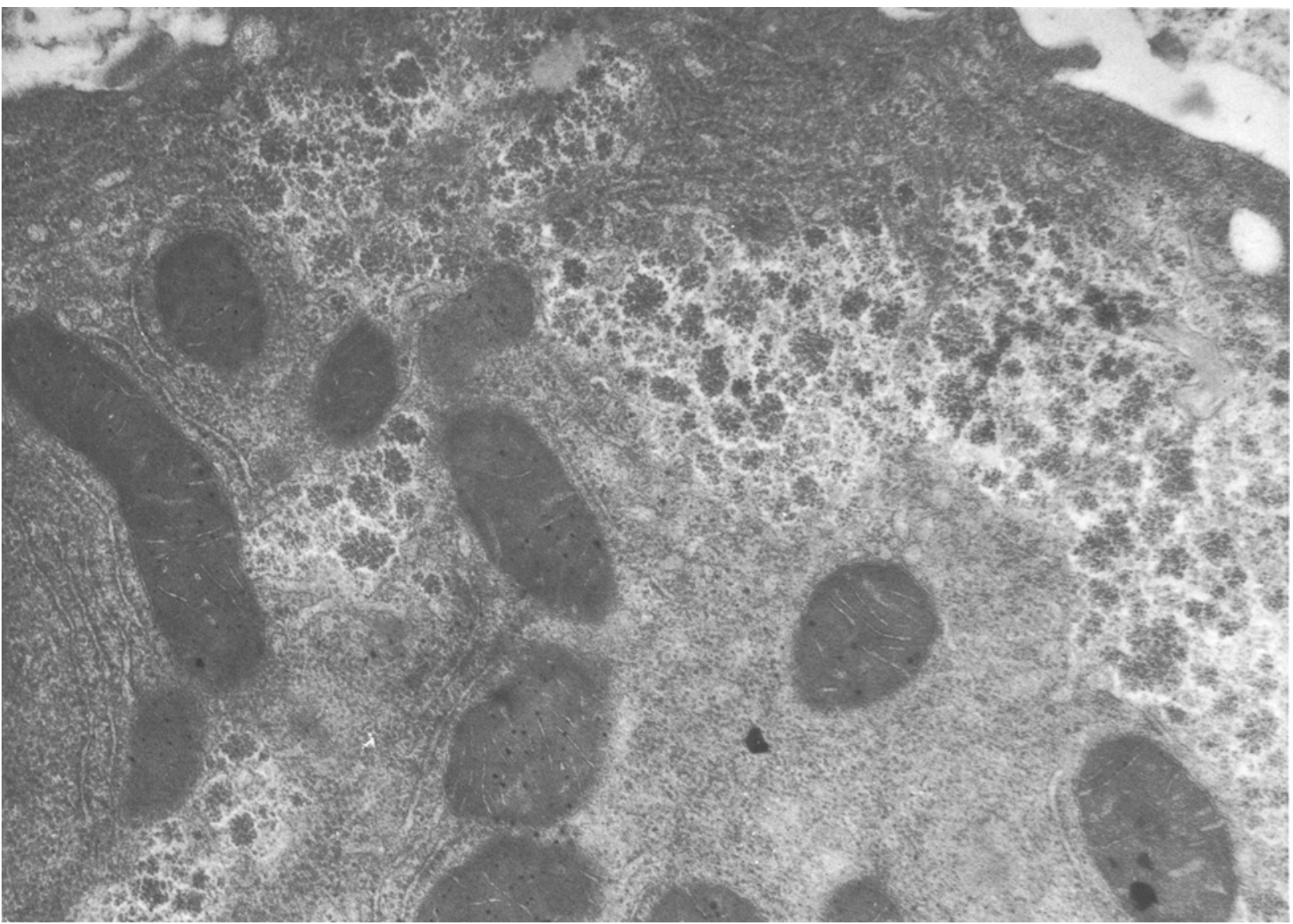

Fig. 2. Electron micrograph $(16000 \times \mathrm{mag})$ of a normal hepatocyte immediately after isolation. Mitochondria and rough endoplasmic reticulum are normal. Parallel strands of polyribosomes are also present. Large amounts of glycogen granules are also seen 


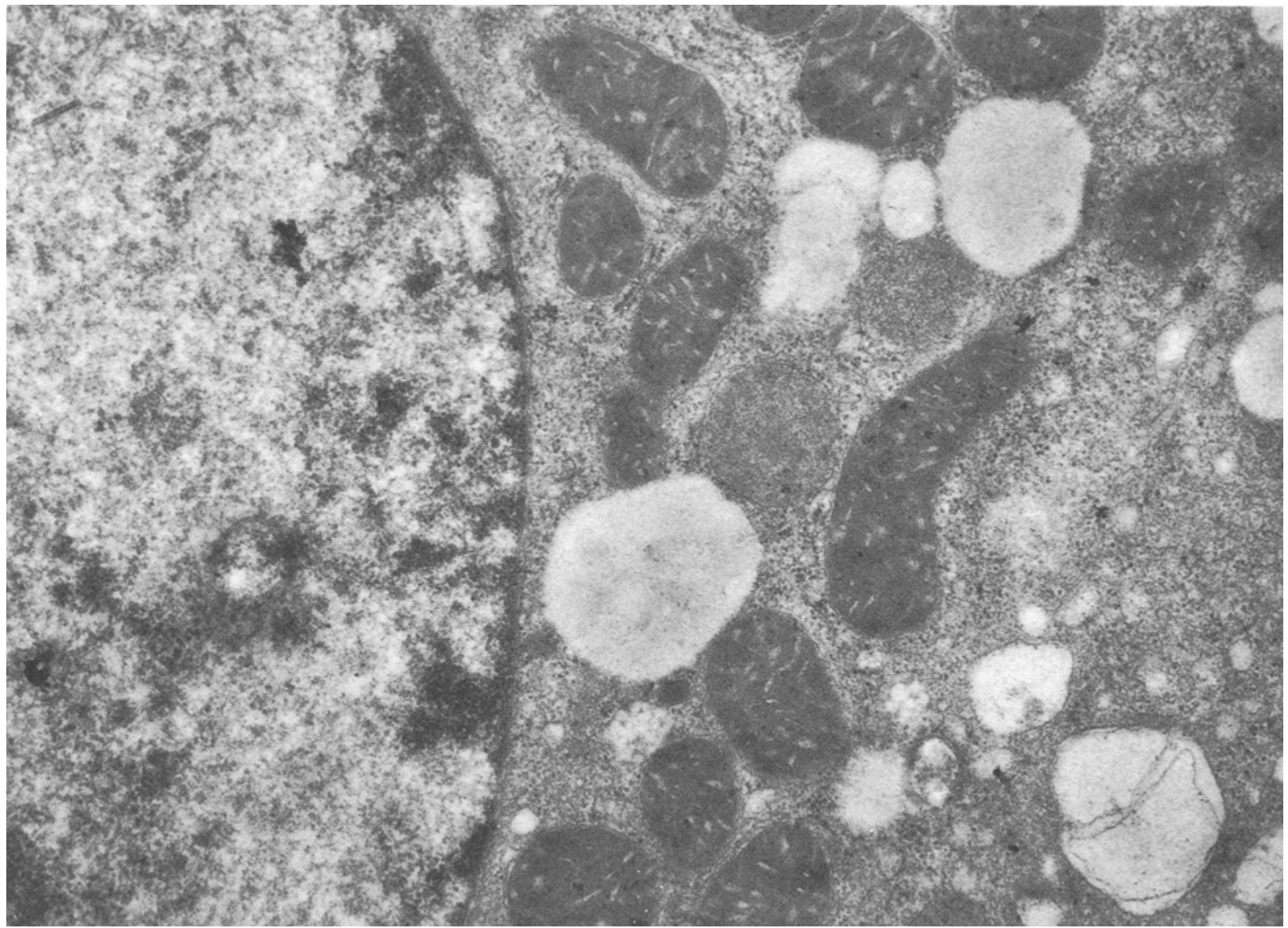

Fig. 3. Electron micrograph $(16000 \times \mathrm{mag})$ of an isolated hepatocyte $(72 \mathrm{hrs}$. after insulin withdrawal $)$ immediately after isolation. Normal nuclear and mitochondrial structure. is seen. There is a significant reduction in polyribosome strands and an increase in smooth endoplasmic reticulum. There is a decrease in glycogen content and an increase in lipids and large vacuoles

Table 1. Effect of Various Concentrations of Lactate on Glucose Production ( $\mu$ moles glucose/g/hr) in Isolated Hepatocytes from Alloxan Diabetic Rats Withdrawn from Insulin at Various Periods of Time

\begin{tabular}{|c|c|c|c|c|c|}
\hline \multicolumn{2}{|l|}{ Lactate } & \multicolumn{4}{|c|}{ Hours after last insulin injection } \\
\hline $\begin{array}{l}\text { Con. } \\
(\mathrm{mM})\end{array}$ & Normal & 0 & 48 & 72 & 96 \\
\hline 0 & $45 \pm 6.2$ & $52 \pm 8.5$ & $10.5 \pm 3.5^{b}$ & $6.6 \pm 1.0^{\mathrm{b}}$ & $3.4 \pm 0.9^{b}$ \\
\hline 5 & $60.5 \pm 8.8$ & $74.6 \pm 9$ & $48.6 \pm 8.0^{\mathrm{b}}$ & $88.8 \pm 12.0^{\mathrm{b}}$ & $51.8 \pm 8.0^{\mathrm{b}}$ \\
\hline 10 & $62.3 \pm 8.2$ & $86.3 \pm 10$ & $60.1 \pm 9.0^{\mathrm{b}}$ & $112.6 \pm 12.0^{\mathrm{b}}$ & $50.3 \pm 8.5^{\mathrm{b}}$ \\
\hline 20 & $58.6 \pm 8.1$ & $84.6 \pm 9.5$ & $56.0 \pm 9.0^{\mathrm{b}}$ & $101.5 \pm 11.0^{\mathrm{b}}$ & $40.1 \pm 7.0^{\mathrm{b}}$ \\
\hline 30 & $50.2 \pm 7.5$ & $78.2 \pm 8$ & $50.0 \pm 7.2^{b}$ & $92.1 \pm 12.0^{\mathrm{b}}$ & $36.5 \pm 6.0^{\mathrm{b}}$ \\
\hline
\end{tabular}

a Approximately $65-75 \mathrm{mg}$ of isolated liver cells were incubated in $3 \mathrm{ml}$ of Ringer bicarbonate buffer at $37^{\circ} \mathrm{C}$ for 1 hour in the presence of various concentration of lactate. Values are expressed in $\mu$ mole glucose $\mathrm{tg} / \mathrm{hr}$ and are mean \pm SEM of 4-6 observations.

b Significantly different from row II and III $(0.05<\mathrm{p}>0.01)$ as determined by the student ' $\mathrm{t}$ ' test.

into protein decreased progressively in liver cells isolated from diabetic rats deprived of insulin for 0 to $96 \mathrm{hr}$. Incorporation of amino acids into protein in cells from diabetic rats withdrawn from insulin for 96 hr was greatly reduced, indicating a significant reduction in protein synthesis. In contrast to the effects of insulin withdrawal, isolated cells from diabetic rats maintained on exogenously administered insulin $(0$ 
Table 2. Effect of Various Concentrations of Fructose on Glucose Production (umoles glucose/g/hr) in Isolated Hepatocytes from Alloxan Diabetic Rats Witharawn from Insulin at Various Periods of Time ${ }^{*}$

\begin{tabular}{|c|c|c|c|c|c|}
\hline \multicolumn{3}{|c|}{ Fructose } & \multicolumn{3}{|c|}{ Hours after last insulin injection } \\
\hline $\begin{array}{l}\text { Con. } \\
\text { (mM) }\end{array}$ & $\begin{array}{l}\text { Normal } \\
\text { Fed }\end{array}$ & 0 & 48 & 72 & 96 \\
\hline 0 & $49.9 \pm 5.8$ & $58.6 \pm 3.9$ & $10.5 \pm 1.0^{\mathrm{b}}$ & $6.6 \pm 10.0^{\mathrm{b}}$ & $3.4 \pm 0.9^{b}$ \\
\hline 5 & $64.6 \pm 8.0$ & $67.8 \pm 11.0$ & $92.0 \pm 10.0^{b}$ & $156.0 \pm 18.0^{\mathrm{b}}$ & $138.0 \pm 16.0^{\mathrm{b}}$ \\
\hline 10 & $74.8 \pm 10.0$ & $96.0 \pm 8.5$ & $105.0 \pm 12.0^{\mathrm{b}}$ & $162.0 \pm 22.0^{\mathrm{b}}$ & $143.0 \pm 32.0^{\mathrm{b}}$ \\
\hline 20 & $70.5 \pm 12.0$ & $90.0 \pm 9.2$ & $99.0 \pm 13.0^{6}$ & $156.0 \pm 21.0^{\mathrm{b}}$ & $136.0 \pm 18.0^{\mathrm{b}}$ \\
\hline 40 & $68.5 \pm 11.0$ & $82.0 \pm 8.5$ & $95.5 \pm 12.0^{\mathrm{b}}$ & $146.0 \pm 20.0^{\mathrm{b}}$ & $130.0 \pm 16.0^{\mathrm{b}}$ \\
\hline
\end{tabular}

a Approximately $65-75 \mathrm{mg}$ of isolated liver cells were incubated in $3 \mathrm{ml}$ of Ringer bicarbonate buffer at $37^{\circ} \mathrm{C}$ for 1 hour in the presence of various concentration of lactate. Values are expressed as $\mu \mathrm{moles} / \mathrm{g} / \mathrm{hr}$ and are mean \pm SEM of 4-6 observations

${ }^{b}$ Significantly different from row II and III $(0.05<\mathrm{p}>0.01)$ as determined by the student ' $t$ ' test.

Table 3. Cyclic AMP Levels in Isolated Liver cells from Alloxan Diabetic Rats (picomoles of cyclic AMP/mg wet wt)

\begin{tabular}{lllll}
\hline & \multicolumn{4}{c}{ Hours after insulin withdrawal } \\
\hline & 0 & 48 & 72 & 96 \\
\hline Unincubated & $0.42 \pm 0.05$ & $0.51 \pm 0.06$ & $0.69 \pm 0.29$ & $0.69 \pm 0.1$ \\
Cells & $(4)$ & $(3)$ & $(4)$ & $(4)$ \\
Incubated & $0.72 \pm 0.15$ & $1.06 \pm 0.22$ & $1.77 \pm 0.60$ & $1.75 \pm 0.3$ \\
Control & $(4)$ & $(3)$ & $(4)$ & $(4)$ \\
Theophylline $1 \mathrm{mM}$ & $0.70 \pm 0.08$ & $1.15 \pm 0.09$ & $2.24 \pm 0.84$ & $1.96 \pm 0.1$ \\
& $(4)$ & $(3)$ & $(4)$ & $(4)$ \\
Glucagon $10^{-6} \mathrm{M}$ & $3.46 \pm 83^{\mathrm{a}}$ & $5.83 \pm 1.60^{\mathrm{ab}}$ & $3.87 \pm 0.62^{\mathrm{ab}}$ & $\begin{array}{l}2.60 \pm 0.46^{\mathrm{ab}} \\
\end{array}$ \\
Theophylline \& & $(4)$ & $(3)$ & $(4)$ & $(4)$ \\
Glucagon & $7.9 \pm 1.2^{\mathrm{a}}$ & $10.2 \pm 0.64^{\mathrm{ab}}$ & $6.4 \pm 1.0^{\mathrm{ab}}$ & $4.34 \pm 0.62^{\mathrm{ab}}$ \\
\hline
\end{tabular}

Isolated liver cells were incubated for $2 \mathrm{~min}$ with or without various drugs. Cyclic AMP was assayed as described in the text. Values are mean \pm SEM of $(N)$ observations.

a Significantly different from above values $(p<0.5)$ as determined by the student ' $t$ ' test.

$\checkmark$ Significantly different from row $I(p<0.05)$ as determined by the student ' $t$ ' test.

Table 4. Incorporation of $\mathrm{C}^{\mathbf{1 4}}$-Isoleucine, Valine and Phenylalanine into Protein by Isolated Liver Cells from Normal and Diabetic Rats (dpm/mg protein)

\begin{tabular}{llllll}
\hline & & & \multicolumn{2}{c}{$\begin{array}{c}\text { Diabetic Rats } \\
\text { Hours after insulin withdrawal }\end{array}$} \\
\hline 10 mM Substrate & Normal Fed Rats & 0 & 48 & 72 & 96 \\
\hline Isoleucine & $869 \pm 58$ & $1477 \pm 124^{\mathrm{a}}$ & $650 \pm 86^{\mathrm{a}}$ & $463 \pm 27^{\mathrm{a}}$ & $286 \pm 57^{\mathrm{a}}$ \\
Valine & $(5)$ & $(5)$ & $(6)$ & $(3)$ & $(5)$ \\
& $1009 \pm 85$ & $1621 \pm 126^{\mathrm{a}}$ & $1176 \pm 118^{\mathrm{a}}$ & $528 \pm 43^{\mathrm{a}}$ & $322 \pm 50^{\mathrm{a}}$ \\
Phenylalanine & $(5)$ & $(5)$ & $(6)$ & $(3)$ & $(4)$ \\
& $764 \pm 65$ & $1206 \pm 119^{\mathrm{a}}$ & $1047 \pm 113^{\mathrm{a}}$ & $435 \pm 85^{\mathrm{a}}$ & $200 \pm 20^{\mathrm{a}}$ \\
& $(5)$ & $(5)$ & $(6)$ & $(3)$ & $(4)$ \\
\hline
\end{tabular}

A $1 \mathrm{ml}$ aliquot of the Unbreit Ringer cell suspension was incubated for $1 \mathrm{hr}$ in $2 \mathrm{ml} \mathrm{g} \mathrm{Umbreit} \mathrm{Ringer} \mathrm{buffer}$ containing $10 \mathrm{mM}$ amino acid, $0.5 \mathrm{uCi}$ of $\mathrm{C}^{14}$-amino acid and $5.5 \mathrm{mM}$ glucose. Values are mean \pm SEM of (N) observations.

a Significantly different from row I $(0.01<\mathrm{p}>0.01)$ as determined by the student ' $\mathrm{t}$ ' test. 
hr) exhibited higher rates of amino acid incorporation into protein than did cells from normal rats (Table 4). The decrease in the incorporation of amino acids into protein observed in liver parenchymal cells from diabetic rats is far greater than that reported by Wagle and Ashmore [4, 5] or by Penhos and Krahl [10] using liver slices from diabetic rats.

\section{Discussion}

The increase in hepatic glucose production in experimental diabetes is well documented $[4-8,18]$ and has been reconfirmed in these studies by using isolated hepatocytes. It has been generally assumed that metabolic alterations which occur in the diabetic liver are due to changes in metabolic pathways in parenchymal cells. The studies presented here confirm that assumption. The massive changes in glucose production and in other variables studied here with isolated hepatocytes in experimental diabetes indicate that hepatocytes, and not other liver cell types, are responsible for the metabolic alterations observed in vivo or with other in vitro preparations.

Hepatic gluconeogenic enzymes increase in diabetes. Pyruvate carboxylase (PC) and phosphoenol pyruvate carboxykinase (PEPCK) increase 3- to 4-fold [19-21] while fructose-1,6-diphosphatase and glucose-6-phosphatase increase only one- to 2 -fold $[7,8]$. Since lactate, pyruvate or alanine enter through PC and PEPCK and fructose enters through triose phosphate and is controlled by fructose-1,6-diphosphatase and glucose-6-phosphatase, the increase in glucose production observed is in agreement with increased activities of these enzymes [7, 8, 19-21]. However, the increase in glucose production in diabetes may not be entirely due to increases in gluconeogenic enzymes. Since amino acid incorporation into protein decreases, endogenous amino acids may be incorporated into glucose. This is in agreement with the observation that the incorporation of exogenously administere ${ }^{14} \mathrm{C}$ amino acids into glucose increases in diabetes [4]. The increase in levels of cyclic AMP observed here and in perfused livers from diabetic rats [22] suggest that this"second messenger" may also be important in maintaining elevated glucose production in experimental diabetes. The decrease in glucagon sensitivity observed $72 \mathrm{hr}$ after insulin withdrawal associated with gluconeogenic capacity may be due to in vivo induction of PEP-carboxykinase at this period. The decrease in glucagon elevation of cyclic AMP levels or the decrease in the incorporation of ${ }^{14} \mathrm{C}$ amino acids into protein in isolated liver cells may have been due to gross deterioration in the metabolic state of the cells. This is, however, unlikely since glucose production remained elevated at 72 and $96 \mathrm{hr}$ while the cyclic AMP response to glucagon diminished and protein synthesis decreased.

Pilkis et al. [22], using perfused liver from alloxan or streptozotocin diabetic rats, have recently confirmed our previous findings [15] that the glucagon response is impaired. They also found that adenylate cyclase activity in plasma membranes from diabetic livers was less responsive to glucagon. The data presented here and that of Pilkis et al. [22] suggest that the receptor site for hormone or some other part of the hepatic receptor-adenylate cyclase complex is altered in diabetes. One or more of the following possibilities may be involved: 1) a decrease in the binding affinity of the receptor for glucagon, 2) a decrease in the number of effective receptor-glucagon interactions, 3) a decrease in the transfer of information from the receptor to adenylate cyclase, 4) a defect in adenylate cyclase or 5) an alteration in some other, as yet undefined, variable. Further studies are needed to resolve the above possibilities.

Garrison and Haynes [23] as well as Johnson et al. [24] have also shown that isolated liver cells respond to hormones. These reports showed that glucagon stimulated gluconeogenesis, glycogenolysis and elevated cyclic AMP levels. The studies presented here indicate that liver cells are sensitive to hormones and should be useful in elucidating mechanisms of hormone interactions. The use of isolated hepatocytes in metabolic studies may take on even more importance in light of the development of the perifused systems for pancreatic islet cells [25] and fat cells [26]. There is no reason to suspect that isolated liver cells cannot be used in such a system, alone or in combination with cells isolated from other tissues. With such systems the interactions between various tissues may be studied in vitro as we have also observed that these isolated hepatocytes respond to various hormones at physiological concentrations [27-30].

\section{References}

1. Renold, A.E., Hastings, A.B., Nesbett, F.B., Ashmore, J.: Studies on carbohydrate metabolism in rat liver slices. 4. Biochemical sequence of events after insulin administration. J. biol. Chem. 213, 135-146 (1955)

2. Spiro, R.G., Hastings, A.: Studies on carbohydrate metabolism in rat liver slices. 11. Effect of prolonged insulin administration to the alloxan-diabetic animal. J. biol. Chem. 230, 751-759 (1958):

3. Spiro, R. G., Ashmore, J., Hastings, A.B.: Studies on carbohydrate metabolism in rat liver slices. 12. Sequence of metabolic events following acute insulin deprivation. J. biol. Chem. 230, 761-771 (1958) 
4. Wagle, S. R., Ashmore, J.: Interrelations between amino acid metabolism and carbohydrate formation in insulin deficiency. $\mathrm{J}$. biol. Chem. 236, 2868-2871 (1961)

5. Wagle, S.R., Ashmore, J.: Studies on experimental diabetes. 3. Effects of acute insulin insufficiency on ${ }^{14} \mathrm{C}$-glucose formation from labeled substrates. J. biol. Chem. 239, 1289-1291 (1964)

6. Wagle, S.R., Ashmore, J.: Studies on experimental diabetes. 2. Carbon dioxide fixation. J. biol. Chem. 238, 17-20 (1963)

7. Wagle, S.R.: Studies on mechanism of glucose synthesis in diabetic and normal rat liver. Diabetes 15, 19-23 (1966)

8. Wagle, S. R.: Studies on mechanism of gluconeogenesis. In: Atti Del Semanario di Studi Biologici (ed. E. Quaghariello) 3, 229-251 (1967)

9. Krahl, M.E.: Effect of insulin on protein synthesis. Diabetes 21 (Suppl. 2), 447-452 (1972)

10. Penhos, J.C., Krahl, M.E.: Insulin stimulus of leucine incorporation in rat liver protein. Amer. J. Physiol. 202, 349-352 (1962)

11. Ingebretsen, W.R., Jr., Wagle, S. R.: A rapid method for the isolation of large quantities of rat liver parenchymal cells with high anabolic rates. Biochem. biophys. Res. Commun. 47, 403-410 (1972)

12. Wagle, S. R., Ingebretsen, W.R., Jr.: Isolation, purification and metabolic characteristics of rat liver hepatocytes. In: Methods in Enzymology (ed. J. Lowenstein) 35 (B), 579-594 (1975)

13. Monier, D., Santhanam, K., Wagle, S. R.: Studies on inhibition of amino acid incorporation into protein by isolated rat liver ribosomes by protein kinase. Biochem. biophys. Res. Commun. 46, 1881-1886 (1972)

14. Gilman, A.G.: A protein binding assay for adenosine 3',5'-cyclic monophosphate. Proc. Nat. Acad. Sci (Wash.) 67, 305-312 (1970)

15. Ingebretsen, W.R., Jr., Moxley, M.A., Allen, D.O., Wagle, S.R.: Studies on gluconeogenesis, protein synthesis, and cyclic AMP levels in isolated parenchymal cells following insulin withdrawal from alloxan diabetic rats. Biochem. biophys. Res. Commun. 49, 601-607 (1972)

16. Hugget, A., Nixon, S.N.: Use of glucose oxidase, peroxidase and $\mathrm{O}$-dianisidine in determination of blood and urinary glucose. Lancet 1957 II, 368-370

17. Reynolds, F.S.: The use of lead citrate and high $\mathrm{pH}$ as an electron-opaque stain in electron microscopy. J. Cell. Biol. 17, 208-212 (1963)

18. Jefferson, L.S., Exton, J.H., Butcher, R. W., Sutherland, E.W., Park, C.R.: Role of adenosine $3^{\prime}, 5^{\prime}$-monophosphate in the effects of insulin and antiinsulin serum on liver metabolism. J. biol. Chem. 243, 1031-1038 (1968)

19. Wagle, S. R.: Studies on pyruvate carboxylase activity in alloxan diabetes and normal animals. Biochem. biophys. Res. Commun. 14, 533-536 (1964)

20. Prinz, W., Seubert, W.: Effect of insulin on pyruvate carboxylase in alloxan diabetic rats. Biochem. biophys. Res. Commun. 16, 582-585 (1964)

21. Freedland, A. D., Kohn, L.: Pyruvate metabolism and control: Factors affecting pyruvate carboxylase activity. Science $\mathbf{1 4 5}$, 58-60 (1964).

22. Pilkis, S. J., Exton, J.H., Johnson, R.A., Park, C.R.: Effects of glucagon on cyclic AMP and carbohydrate metabolism in livers from diabetic rats. Biochim. biophys. Acta (Amst.) 343, 205-267 (1974)

23. Garrison, J.C., Haynes, R.C., Jr.: Hormonal control of glycogenolysis and gluconeogenesis in isolated rat liver cells. J. biol. Chem. 248, 5333-5343 (1973)

24. Johnson, R.E.M., Das, N.M., Butcher, F.R., Fain, F.N.: The regulation of gluconeogenesis in isolated rat liver cells by glucagon, insulin, dibutyryl cyclic adenosine monophosphate and fatty acids. J. biol. Chem. 247, 3229-3235 (1972)

25. Hoshi, M., Shreeve, W.W.: Release and production of insulin by isolated, perifused rat pancreatic islets: Control by glucose. Diabetes 212, 16-24 (1973)

26. Allen, D. O., Largis, E.E., Miller, E. A., Ashmore, J.: Continuous monitoring of lipolytic rates in perifused isolated fat cells. J. appl. Physiol. 34, 125-127 (1973)

27. Wagle, S.R., Ingebretsen, W.R., Jr.: Stimulation of glycogenolysis by epinephrine and glucagon and its inhibition by insulin in isolated hepatocytes. Biochem. biophys. Res. Commun. 52, 125-129 (1973)

28. Wagle, S. R., Ingebretsen, W.R., Jr., Sampson, L.: Studies on the in vitro effects of insulin on glycogen synthesis and ultrastructure in isolated rat liver hepatocytes. Biochem. biophys. Res. Commun. 53, 937-943 (1973)

29. Akpan, J.O., Gardner, R.M., Wagle, S.R.: Studies on the effects of insulin and acetylcholine on activation of glycogen synthase and glycogenesis in hepatocytes. Biochem. biophys. Res. Commun. 61, 222-229 (1974)

30. Moxley, M.A., Bell, N.H., Wagle, S.R., Allen, D.O., Ashmore, J.: Parathyroid hormone stimulation of glucose and urea production in isolated liver cells. Amer. J. Physiol. 227, 1058-1061 (1974)

Prof. S. R. Wagle

Dept. of Pharmacology

Indiana Ưniv. School

of Medicine

1100 West Michigan Street

Indianapolis, Indiana 46202

USA 